\title{
EDUKASI DENGAN MEDIA AUDIOVISUAL TERHADAP PERILAKU CUCI TANGAN PADA KELUARGA PASIEN RAWAT INAP
}

\author{
Wahyuningsih Safitri $^{1)}$, Nining Wihastutik ${ }^{2)}$, Anis Nurhidayati ${ }^{3)}$, Heni Nur Kusumawati ${ }^{4)}$ \\ 1),2),3) Universitas Kusuma Husada Surakarta \\ 4)Poltekkes Kemenkes Surakarta \\ e-mail: wahyuningsihsafitri@gmail.com
}

\begin{abstract}
ABSTRAK
Penyakit infeksi merupakan penyebab utama tingginya angka kesakitan dan kematian di dunia. Upaya untuk mencegah terjadinya infeksi nosokomial adalah dengan menjalankan universal precautian yang salah satunya dengan mencuci tangan pada setiap penanganan pasien di rumah sakit. Edukasi dengan media audio visual lebih menarik dan lebih mudah dipahami dan diharapkan keluarga pasien mempunyai perilaku cuci tangan yang benar. Penelitian ini bertujuan untuk mengetahui pengaruh edukasi dengan media audiovisual terhadap perilaku cuci tangan pada keluarga pasien. Jenis penelitian yang digunakan adalah penelitian kuantitatif, menggunakan rancangan penelitian quasi eksperiment dengan Non-equivalent control group design. Populasi dalam penelitian ini adalah semua keluarga pasien sebanyak 98 orang. Pengambilan sampel dalam penelitian ini menggunakan stratified proportionate random sampling. Analisa data dalam penelitian ini menggunakan uji Mann-Whitney. Hasil penelitian menunjukkan ada pengaruh edukasi media audiovisual terhadap perilaku cuci tangan pada keluarga pasien rawat inap dengan $p$ value 0,011. Hasil penelitian ini dapat menjadi rujukan dalam meningkatkan perilaku kesehatan melalui media audiovisual
\end{abstract}

Kata Kunci: edukasi, audiovisual, perilaku, cuci tangan

\begin{abstract}
Infectious diseases are the main cause of high morbidity and mortality rates in the world. Efforts to prevent the occurrence of nosocomial infections is to carry out universal precautian, one of which is by washing hands in every handling of patients in the hospital. Education with audio visual media is more interesting and easier to understand and it is expected that the patient's family has the correct hand washing behavior. This study aims to determine the effect of education with with audio visual media on hand washing behavior in patients' families.This type of research is quantitative research, using a quasiexperimental research design with Non-equivalent control group design. The population in this study were all patients' families as many as 98 people. Sampling in this study used a stratified proportionate random sampling. Analysis of the data in this study using the Mann-Whitney test. The results showed there was an influence of audio visual media on hand washing behavior in the families of inpatients with a $p$ value of 0.011 . The results of this study can be a reference in improving health behavior through audiovisual media
\end{abstract} Keywords: education, audiovisual, behavior, washing hands

\section{PENDAHULUAN}

Penyakit infeksi masih
merupakan penyebab utama
tingginya angka kesakitan dan
kematian di dunia. Salah satu jenis
infeksi adalah infeksi nosokomial.

Prevalensi Infeksi nosokomial atau Healthcare Associated Infections (HAIs) di rumah sakit dunia mencapai 9\% atau kurang lebih 1,4 juta pasien rawat inap di rumah sakit seluruh dunia 
terkena infeksi nosokomial. Penelitian yang dilakukan oleh WHO menunjukkan bahwa sekitar 8,70\% dari 55 rumah sakit di 14 negara yang berada di Eropa, Timur Tengah, Asia Tenggara, dan Pasifik menunjukkan adanya HAIs. Prevalensi HAIs paling banyak di Mediterania Timur dan Asia Tenggara yaitu sebesar 11,80\% dan $10 \%$ sedangkan di Eropa dan Pasifik Barat masing-masing sebesar 7,70\% dan 9\% (Kurniawati, Satyabakti, \& Arbianti, 2015).

Upaya untuk mencegah terjadinya infeksi nosokomial adalah dengan menjalankan universal precautian yang salah satunya adalah dengan mencuci tangan pada setiap penanganan pasien di rumah sakit. Menurut Kusumaningtyas (2013), mencuci tangan dapat menurunkan 20\% - $40 \%$ kejadian infeksi nosokomial. Kontak secara langsung dari keluarga pasien saat rawat inap di rumah sakit yang tidak cuci tangan dapat membahayakan kesehatan bagi pasien yang bersangkutan (Hart, $\mathrm{T}$ dan Shears, 2009). Menurut Fajriyah (2015) pasien atau keluarga pasien yang tidak melakukan cuci tangan dengan baik mempunyai andil dalam penulisan infeksi nosokomial.

Penelitian Mumpuningtias, dkk (2017) menjelaskan bahwa sebagian besar tingkat pengetahuan keluarga pasien tentang handrub dalam kategori tingkat pengetahuan kurang (60\%), sebagian besar keluarga pasien tidak melakukan mencuci tangan menggunakan handrub yaitu sebanyak $81,7 \%$, dan ada hubungan antara tingkat pengetahuan dengan perilaku cuci tangan menggunakan handrub pada keluarga pasien $(p=0,000)$.

Berdasarkan data di Ruang Rawat Inap Rumah Sakit Kasih Ibu Surakarta kepada beberapa keluarga pasien diketahui bahwa keluarga pasien jarang melakukan cuci tangan dalam 5 moment meskipun sudah terdapat hand rub yang disediakan di depan pintu masuk ruang dan di dalam kamar perawatan pasien karena keluarga pasien tidak mengetahui cara mencuci tangan yang benar.

Menurut Majid (2013), beberapa kelebihan yang didapat jika penyuluhan yang disajikan dalam bentuk video visual lebih menarik dan lebih mudah dipahami, dengan video seseorang dapat belajar sendiri, dapat diulang pada bagian tertentu yang perlu lebih jelas, dapat menampilkan sesuatu yang detail, dapat dipercepat maupun diperlambat, memungkinkan utuk membandingkan antara dua adegan berbeda diputar dalam waktu bersamaan, dan dapat digunakan sebagai tampilan nyata dari suatu adegan, suatu situasi diskusi, dokumentasi, promosi suatu produk, interview, dan menampilkan satu percobaan yang berproses.

Berdasarkan latar belakang tersebut maka akan dilakukan penelitian edukasi dengan media audiovisual terhadap perilaku cuci tangan pada keluarga pasien saat rawat inap.

\section{METODOLOGI}

Jenis penelitian ini adalah penelitian quasi eksperiment dengan rancangan yang digunakan nonequivalent control group design yaitu sebelum dilakukan intervensi, peneliti melakukan observasi terlebih dahulu (pretest) untuk mengetahui perilaku pasien sebelum dilakukan intervensi kemudian dilakukan pengukuran (post test) setelah pemberian intervensi dengan media audiovisual untuk mengetahui perilaku pasien sesudah dilakukan intervensi perilaku cuci tangan pada keluarga pasien rawat inap. Penelitian dilaksanakan pada bulan Maret-April 2019. Populasi dalam penelitian ini adalah semua 
keluarga pasien di ruang rawat inap Rumah Sakit Kasih Ibu Surakarta, yang rata-rata per bulannya sebanyak 3647 pasien. Teknik sampling yang digunakan dalam penentuan sampel dalam penelitian ini adalah dengan teknik probability sampling yaitu teknik pengambilan sampel secara random atau acak dengan jumlah 98 orang yang dibagi menjadi dua kelompok. Analisa data menggunakan uji wilcoxon untuk mengetahui perubahan pre dan post test sedangkan uji beda kelompok intervensi dan kontrol menggunakan uji mann whitney.

\section{HASIL DAN PEMBAHASAN}

a. Karakteristik responden

Tabel 1 Karakteristik responden berdasarkan umur

\begin{tabular}{lcccc}
\hline \multicolumn{1}{c}{ Umur } & $\mathrm{X}$ & Med & SD & $\begin{array}{c}\text { Min- } \\
\text { Max }\end{array}$ \\
\hline Kontrol & 35,5 & 31 & 10,5 & $22-60$ \\
Intervensi & 36,8 & 31 & 13,9 & $18-73$ \\
\hline \multicolumn{4}{c}{ Berdasarkan } & \multicolumn{2}{c}{ Tabel } & 1
\end{tabular}

diketahui rata-rata usia responden pada kelompok intervensi adalah 35,5 , dengan median 31 , dan SD 10,5. Usia minimum 22 dan maksimum 60. Rata-rata usia responden pada kelompok kontrol adalah 36,8 , dengan median 31 , dan SD 13,9. Usia minimum 18 dan maksimum 73. Menurut Depkes (2009) pada rentan usia 36-45 tahun adalah tahap dewasa akhir, semakin bertambahnya umur seseorang akan terjadi perubahan pada aspek fisik dan psikologis (mental). Pada aspek psikologi atau mental taraf berfikir seseorang semakin matang dan dewasa. Usia responden ini termasuk usia dewasa akhir sehingga mereka dapat dikatakan mempunyai pengalaman dan wawasan yang cukup banyak. Hasil penelitian ini didukung oleh penelitian Ferdinah (2017) yang menunjukkan mayoritas responden berusia dewasa awal sebanyak 65 orang $(69,1 \%)$.

Menurut Rachmawati (2016) umur mempunyai pengaruh terhadap daya tangkap dan pola pikir seseorang. Semakin bertambah usia akan semakin berkembang pula daya tangkap dan pola pikirnya serta diharapkan mampu mempraktikan. Semakin meningkatnya usia seseorang diharapkan juga psikologis dan kedewasaannya ikut meningkat sehingga mampu menunjukkan kematangan dalam berfikir dan bertindak, serta pengambilan keputusan yang semakin bijak (Septiani, 2016).

Penelitian ini juga didukung oleh penelitian yang dilakukan oleh Setiawati (2009) dan Damanik (2012) yang menunjukkan bahwa petugas kesehatan dengan rentang usia dewasa awal (18-40 tahun) lebih banyak tidak taat dalam melakukan hand hygiene, sehingga diperoleh bahwa petugas kesehatan pada rentang usia dewasa madya (>40-60 tahun) mempunyai peluang 0,94 kali untuk taat melakukan hand hygiene dibandingkan dengan petugas kesehatan pada rentang usia dewasa awal.

Menurut pendapat peneliti, dengan kategori usia ini responden mempunyai pengalaman dan wawasan mengenai cuci tangan dan dapat lebih mengerti jika sudah diberikan pendidikan kesehatan.

Tabel 2 Karakteristik responden berdasarkan jenis kelamin.

\begin{tabular}{lcccc}
\hline \multirow{2}{*}{$\begin{array}{c}\text { Jenis } \\
\text { kelamin }\end{array}$} & \multicolumn{2}{c}{ Kontrol } & \multicolumn{2}{c}{ Intervensi } \\
\cline { 2 - 5 } & $\mathrm{f}$ & $\%$ & $\mathrm{f}$ & $\%$ \\
\hline Laki-laki & 21 & 42,9 & 17 & 34,7 \\
Perempuan & 28 & 57,1 & 32 & 65,3 \\
\hline Jumlah & 49 & 100 & 49 & 100 \\
\hline
\end{tabular}


Tabel 2 menunjukan karakteristik responden berdasarkan jenis kelamin, pada kelompok intervensi jumlah jenis kelamin terbanyak perempuan sejumlah 32 orang $(65,3 \%)$, sedangkan untuk kelompok kontrol jenis kelamin terbanyak yaitu perempuan sejumlah 28 orang $(57,1 \%)$. Hasil penelitian ini diperkuat oleh penelitian yang dilakukan oleh Iskandar, dkk (2018) yang menjelaskan bahwa jenis kelamin keluarga pasien kelompok intervensi sejumlah $85.0 \%$ perempuan, sedangkan keluarga pasien kelompok kontrol terdiri $60.0 \%$ perempuan.

Menurut Bernard dalam Setyaningsih (2009) karakteristik feminin lebih memperlihatkan sifat-sifat wanita seperti penyabar, rapi, telaten, ramah, lemah kembut, dan penyayang sehingga keluarga pasien yang menunggu pasien di ruang rawat inap sesuai dengan kerakteristik perempuan.

Menurut pendapat peneliti, mayoritas sampel dalam penelitian ini adalah perempuan pada kelompok kontrol maupun kelompok intervensi dikarenakan perempuan memiliki sifat penyabar, rapi, telaten, ramah, lemah kembut, dan penyayang sehingga keluarga pasien mayoritas yaitu perempuan.

Tabel 3 Karakteristik responden berdasarkan pendidikan

\begin{tabular}{|c|c|c|c|c|}
\hline \multirow{2}{*}{ Pendidikan } & \multicolumn{2}{|c|}{ Kontrol } & \multicolumn{2}{|c|}{ Intervensi } \\
\hline & $\mathrm{f}$ & $\%$ & $\mathrm{f}$ & $\%$ \\
\hline SD & 3 & 6,1 & 5 & 10,3 \\
\hline SLTP & 6 & 12,2 & 3 & 6,1 \\
\hline SLTA & 20 & 40,8 & 16 & 32,7 \\
\hline Perguruan Tinggi & 20 & 40,8 & 25 & 51,0 \\
\hline Jumlah & 98 & 100 & 98 & 100 \\
\hline menunjuk & & $\begin{array}{l}\text { tabel } \\
\text { carakt }\end{array}$ & stik & \\
\hline
\end{tabular}

pada kelompok intervensi jumlah Pendidikan terbanyak Perguruan Tinggi sejumlah 25 orang (51\%), sedangkan untuk kelompok kontrol pendidikan terbanyak yaitu SLTA dan Perguruan Tinggi masingmasing sejumlah 20 orang $(40,8 \%)$. Hal ini berarti mayoritas responden baik pada kelompok intervensi maupun kelompok kontrol berpendidikan tinggi, artinya mereka telah dapat memahami dan menggali informasi secara cepat dan mudah. Hasil penelitian ini diperkuat oleh penelitian yang dilakukan oleh Raharjo, dkk (2017) yang menghasilkan penelitian bahwa terdapat 29 orang di kelompok intervensi dan kelompok kontrol dimana sebagian besar responden memiliki pendidikan PT dan SMA pada kelompok intervensi sebanyak 14 orang $(48,3 \%)$ dan kelompok kontrol sebanyak 14 orang $(48,3 \%)$.

Pendidikan seseorang akan mempengaruhi perbedaan pengetahuan. Hal tersebut dikarenakan pendidikan mempengaruhi proses belajar, semakin tinggi pendidikan seseorang maka daya tangkap terhadap informasi semakin tinggi, sehingga akan semakin mudah umtuk menerima informasi. Handojo (2015) juga menyatakan bahwa tingkat pendidikan akan mempengaruhi pengetahuan dan penerimaan seseorang terhadap suatu informasi.

Menurut pendapat peneliti, mayoritas pendidikan responden pada penelitian ini adalah perguruan tinggi. Tidak dapat dipungkiri bahwa makin tinggi pendidikan seseorang semakin mudah pula mereka menerima informasi, dan pada akhirnya makin banyak pula pengetahuan yang dimilikinya. 
Tabel 4 Karakteristik responden berdasarkan pekerjaan

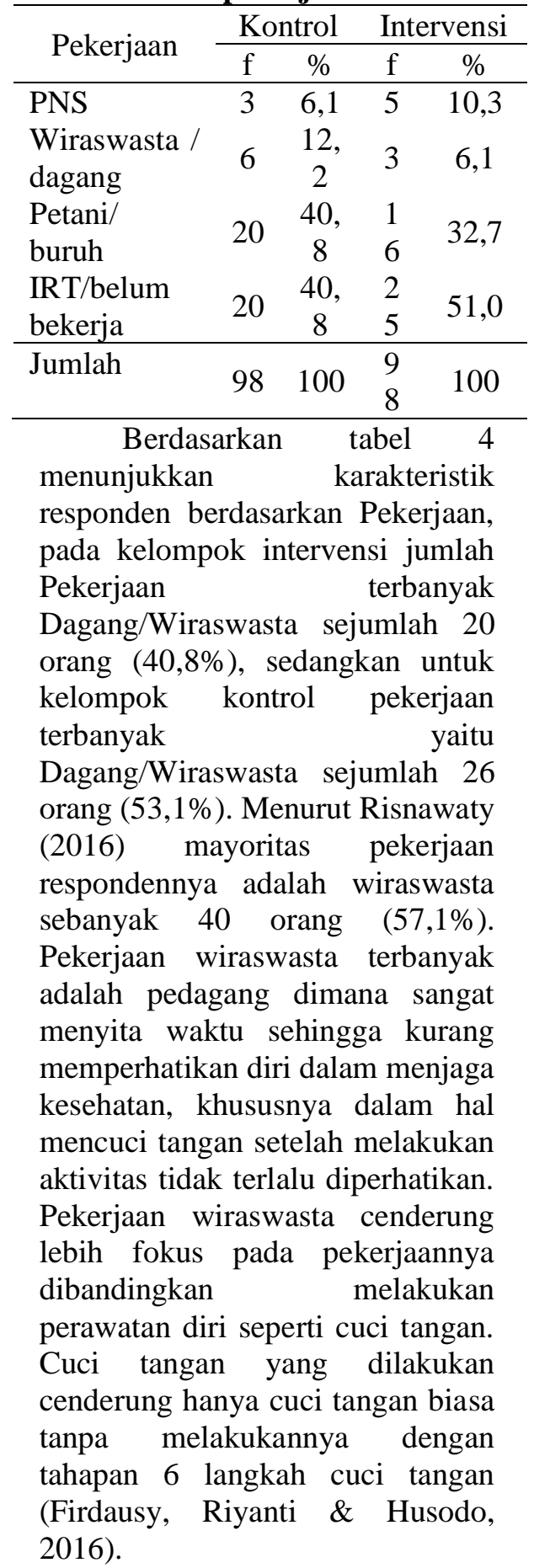

Menurut pendapat peneliti, penelitian ini mayoritas responden adalah dagang/wiraswasta, dimana lingkungan pekerjaan membuat seseorang mendapatkan pengalaman dan informasi baik secara langsung maupun tidak langsung.

a. Perilaku cuci tangan pre test keluarga pasien kelompok kontrol dan kelompok intervensi

Tabel 5 Perilaku cuci tangan pre test keluarga pasien kelompok kontrol dan kelompok intervensi

\begin{tabular}{lcccc}
\hline \multirow{2}{*}{$\begin{array}{c}\text { Perilaku } \\
\text { cuci tangan }\end{array}$} & \multicolumn{2}{c}{ Kontrol } & \multicolumn{2}{c}{ Intervensi } \\
\hline Tidak baik & 23 & 46,9 & 41 & 83,7 \\
Baik & 26 & 53,1 & 8 & 16,3 \\
\hline Jumlah & 49 & 100 & 49 & 100 \\
\hline \multicolumn{3}{c}{ Tabel } & 5 & menunjukkan hasil
\end{tabular}
pre test perilaku cuci tangan, mayoritas perilaku cuci tangan pada kelompok intervensi tidak melakukan dengan baik yaitu sebanyak 41 orang $(83,7 \%)$. Adapun mayoritas perilaku cuci tangan pada kelompok kontrol tergolong melakukan dengan baik yaitu sebanyak 26 orang $(53,1 \%)$. Penelitian Iskandar \& Yanto (2018) yang menunjukkan mayoritas responden memiliki perilaku cuci tangan kurang baik sebanyak 40 orang (100\%).

Kurangnya pengetahuan keluarga pasien tentang cuci tangan tampaknya juga disebabkab karena letak handrub yang mudah terlewatkan dari pandangan mata dan pamflet tentang langkahlangkah cuci tangan menggunakan handrub yang agak kecil sehingga sering luput dari perhatian. Selain itu kurangnya komunikasi antara petugas kesehatan dan keluarga pasien juga menjadi salah satu faktor kurangnya pengetahuan, sehingga terjadi kesalahpahaman seperti anggapan bahwa handrub hanya boleh digunakan oleh petugas rumah sakit saja (Mumpuningtias, Aliftitah \& Illiyini, 2018).

Menurut pendapat peneliti menyatakan bahwa perilaku cuci 
tangan pada kelompok kontrol dan intervensi masih kurang baik karena kurangnya informasi dan pelatihan tentang cuci tangan 6 langkah yang baik dan benar sehingga perilaku cuci tangan mereka masih kurang baik

b. Perilaku cuci tangan post test keluarga pasien kelompok kontrol dan kelompok intervensi

Tabel 6 Perilaku cuci tangan post test keluarga pasien kelompok kontrol dan kelompok intervensi

\begin{tabular}{lcccc}
\hline Perilaku cuci & \multicolumn{2}{c}{ Kontrol } & \multicolumn{2}{c}{ Intervensi } \\
\cline { 2 - 5 } tangan & $\mathrm{f}$ & $\%$ & $\mathrm{f}$ & $\%$ \\
\hline Tidak baik & 23 & 46,9 & 10 & 20,4 \\
Baik & 26 & 53,1 & 39 & 79,6 \\
\hline Jumlah & 49 & 100 & 49 & 100
\end{tabular}

Tabel 6 menunjukkan hasil post test perilaku cuci tangan, mayoritas perilaku cuci tangan pada kelompok intervensi melakukan dengan baik yaitu sebanyak 39 orang $(79,6 \%)$. Adapun mayoritas perilaku cuci tangan pada kelompok kontrol tergolong melakukan dengan baik yaitu sebanyak 26 orang $(53,1 \%)$. Hasil penelitian ini didukung oleh penelitian Rachmawati (2016) yang menunjukkan bahwa mayoritas responden memiliki perilaku cuci tangan yang baik setelah pemberian pendidikan kesehatan melalui media video sebanyak 58 orang $(100 \%)$.

Metode video ini selain untuk media hiburan dan media komunikasi juga dapat digunakan sebagai media edukasi yang mudah dipahami masyarakat dari anakanak hingga orang tua (Prastowo, 2012). Informasi yang disampaikan melalui video dapat diterima secara maksimal, sehingga dapat mengaplikaskan praktik cuci tangan yang baik dan benar (Sadiman, 2012).
Menurut pendapat peneliti bahwa perilaku cuci tangan setelah pemberian pendidikan kesehatan melalui media video menunjukkan peningkatan yang signifikan karena media video dapat diserap dan dipahami dengan mudah dibandingkan media lain.

c. Perbedaan perilaku cuci tangan pre test dan post test edukasi dengan demonstrasi (kontrol)

Tabel 7 Perbedaan perilaku cuci tangan pre test dan post test edukasi dengan demonstrasi (kontrol)

\begin{tabular}{|c|c|c|c|}
\hline $\begin{array}{c}\text { Perilaku } \\
\text { cuci tangan }\end{array}$ & Mean & $Z$ & $\begin{array}{c}P \\
\text { value }\end{array}$ \\
\hline Pre test & 3,63 & 5888 & 0.000 \\
\hline Post test & 6,37 & 5,888 & 0,000 \\
\hline
\end{tabular}

Tabel 7 menunjukan hasil uji Wilcoxon dengan nilai $p$-value $=$ $0,000<0,05$ maka keputusan yang diambil adalah $\mathrm{H}_{0}$ ditolak karena $p$ value $<0,05$. Artinya ada perbedaan rata-rata perilaku cuci tangan pada keluarga pasien rawat inap sebelum dan sesudah diberi edukasi dengan media demonstrasi di ruang rawat inap Rumah Sakit Kasih Ibu Surakarta. Hasil penelitian ini didukung oleh penelitian Roheti, Windyastuti \& Pangesti (2019) yang menunjukkan bahwa media demonstrasi dapat meningkatkan perilaku cuci tangan dengan nilai $\mathrm{p}$ value 0,000 .

Metode demonstrasi secara khusus dirancang untuk mempromosikan belajar anak dengan pengetahuan prosedural yang terstruktur dengan baik dan dapat diajarkan secara langkah demi langkah terhadap anak (Pierangelo \& Giulani, 2010).

Menurut pendapat peneliti bahwa responden yang diberikan pendidikan kesehatan menggunakan media demonstrasi dapat meningkatkan perilaku cuci tangan karena dapat memberikan 
gambaran yang jelas tentang cara cuci tangan yang baik dan benar

d. Perbedaan perilaku cuci tangan pre test dan post test edukasi dengan media audiovisual

Tabel 8 Perbedaan perilaku cuci tangan pre test dan post test edukasi dengan media audiovisual

\begin{tabular}{lccc}
$\begin{array}{c}\text { Perilaku cuci } \\
\text { tangan }\end{array}$ & Mean & $Z$ & $\begin{array}{c}P \\
\text { value }\end{array}$ \\
\hline Pre test & 3,55 & 5,59 & 0,000 \\
Post test & 6,57 & & \\
\hline
\end{tabular}

Tabel 8 menunjukan hasil uji Wilcoxon dengan nilai $p$-value $=$ $0,000<0,05$ maka keputusan yang diambil adalah Ho ditolak karena $p$ value $<0,05$. Artinya ada perbedaan rata-rata perilaku cuci tangan pada keluarga pasien rawat inap sebelum dan sesudah diberi edukasi dengan media audiovisual di ruang rawat inap Rumah Sakit Kasih Ibu Surakarta.

$\begin{array}{llr}\text { (2013) } & \text { setelah dilakukan } \\ \text { pendidikan } & \text { kesehatan dengan }\end{array}$ metode audiovisual yang berisi tentang cuci tangan yang benar, responden mengalami kenaikan yang berperilaku baik terhadap cuci tangan sebanyak 29 anak $(93,5 \%)$. Melakukan pendidikan kesehatan memiliki keuunggulan karena dapat menyampaikan hal yang konkrit dan mudah dimengerti.

Menurut pendapat peneliti bahwa terdapat perubahan pada hasil post test dimana terdapat peningkatan perilaku cuci tangan pada kelompok intervensi yang melakukan dengan baik yaitu sebanyak 39 orang $(79,6 \%)$.

e. Pengaruh edukasi dengan media audiovisual dan demonstrasi terhadap perilaku cuci tangan pada keluarga pasien rawat inap di Rumah Sakit Kasih Ibu Surakarta
Tabel 9 Pengaruh edukasi dengan media audiovisual dan demonstrasi terhadap perilaku cuci tangan pada keluarga pasien rawat inap di Rumah Sakit Kasih Ibu Surakarta

\begin{tabular}{|c|c|c|c|}
\hline $\begin{array}{c}\text { Perilaku } \\
\text { cuci tangan }\end{array}$ & Mean & $Z$ & $\begin{array}{c}P \\
\text { value }\end{array}$ \\
\hline $\begin{array}{l}\text { Media } \\
\text { youtube }\end{array}$ & 55,57 & $-2,533$ & 0,011 \\
\hline Demonstrasi & 43,43 & & \\
\hline
\end{tabular}
menunjukkan hasil uji mann whitney dengan nilai $Z$-test $=$ 2,533 dengan $p$-value $=0,011<$ 0,05 maka keputusan adalah Ho ditolak, artinya terdapat pengaruh edukasi dengan media audiovisual dan media demonstrasi terhadap perilaku cuci tangan pada keluarga pasien rawat inap di Rumah Sakit Kasih Ibu Surakarta.

Efektivitas penggunaan kedua media edukasi antara media audiovisual dengan media demonstrasi, media audiovisual lebih efektif untuk meningkatkn perilaku cuci tangan. Edukasi dengan video seseorang dapat belajar sendiri, dapat diulang pada bagian tertentu yang perlu lebih jelas, dapat menampilkan sesuatu yang detail, dapat dipercepat maupun diperlambat, dan memungkinkan utuk membandingkan antara dua adegan berbeda diputar dalam waktu bersamaan, serta dapat digunakan sebagai tampilan nyata dari suatu adegan, suatu situasi diskusi, dokumentasi, promosi suatu produk, interview, dan menampilkan satu percobaan yang berproses (Sadiman, 2012).

\section{SIMPULAN}

a. Rata-rata usia responden pada kelompok intervensi adalah 35,5, dengan median 31, dan SD 10,5. Usia minimum 22 dan maksimum 60. 
Rata-rata usia responden pada kelompok kontrol adalah 36,5, dengan median 31, dan SD 13,9. Usia minimum 18 dan maksimum 73, mayoritas responden kelompok intervensi terbanyak yaitu berjenis kelamin perempuan sejumlah 32 orang $(65,3 \%)$, sedangkan untuk kelompok kontrol jenis kelamin terbanyak yaitu laki-laki sejumlah 21 orang $(42,9 \%)$, pada kelompok intervensi jumlah Pendidikan terbanyak yaitu Perguruan Tinggi sejumlah 25 orang (51\%), sedangkan untuk kelompok kontrol pendidikan terbanyak yaitu SLTA dan Perguruan Tinggi sejumlah 20 orang $(40,8 \%)$. pada kelompok intervensi jumlah Pekerjaan terbanyak yaitu Dagang/Wiraswasta sejumlah 20 orang $(40,8 \%)$, sedangkan untuk kelompok kontrol pekerjaan terbanyak yaitu Dagang/Wiraswasta sejumlah 26 orang $(53,1 \%)$.

b. Hasil pre test perilaku cuci tangan yaitu mayoritas perilaku cuci tangan pada kelompok intervensi tidak melakukan dengan baik yaitu sebanyak 41 orang $(83,7 \%)$. Adapun mayoritas perilaku cuci tangan pada kelompok kontrol tergolong melakukan dengan baik yaitu sebanyak 26 orang $(53,1 \%)$.

c. Hasil post test perilaku cuci tangan yaitu mayoritas perilaku cuci tangan pada kelompok intervensi melakukan dengan baik yaitu sebanyak 39 orang $(79,6 \%)$. Adapun mayoritas perilaku cuci tangan pada kelompok kontrol tergolong melakukan dengan baik yaitu sebanyak 26 orang $(53,1 \%)$.

d. Hasil penelitian menunjukkan Nilai $Z$-test $=-2,533$ dengan $\mathrm{p}$-value $=$ $0,011<0,05$ maka keputusan adalah Ho ditolak, artinya terdapat pengaruh edukasi dengan media audiovisual terhadap perilaku cuci tangan pada keluarga pasien rawat inap di Rumah Sakit Kasih Ibu Surakarta

\section{REFERENSI}

Achmad, I. (2017). Manajemen perawatan pasien total care dan kejadian infeksi nosokomial di ruang ICU RSUD Masohi tahun 2016. Global Health Science, 2(1), 319-324.

Alimul, A. Hidayat. (2010). Metode Penelitian dan Analisis Data. Jakarta: Salemba Medika.

Andriani, T. (2015). Sistem Pembelajaran Berbasis Teknologi Informasi dan Komunikasi. Jurnal Sosial Budaya. Vol.12:1.

Darmadi, (2008). Infeksi Nosokomial Problematika dan Pengendaliannya, Jakarta : Salemba Medika.

Desianto, (2013). Efektivitas Mencuci Tangan Menggunakan Cairan Pembersih Tangan Antiseptik (Hand Sanitizer) Terhadap Jumlah Angka Kuman. Kesmas, Vol.7, No.2, September 2013, ISSN: 1978-0575.

Dewitt, D., Alias, N., Siraj, S., Yaakub, M. Y., Ayob, J., \& Ishak, R. (2013). The potential of Youtube for teaching and learning in the performing arts. ProcediaSocial and Behavioral Sciences, 103, 1118-1126. https://doi.org/10.1016/j.sbspro.2 013.10.439

Duncan, I., Yarwood-ross, L., \& Haigh, C. (2013). Nurse Education Today Youtube as a source of clinical skills education. YNEDT, 33(12), 1576-1580. https://doi.org/10.1016/j.nedt.201 2.12.013

Fajriyah, N.N., (2015). Pengetahuan Mencuci Tangan Penunggu Pasien Mengunakan Lotion Antiseptic. The 2nd University Research Coloquium 2015. Hasil Prosiding. Seminar Nasional dan Internasional. Semarang: Unimus. 
Ferdinah, R. (2017). Gambaran Perilaku Hand Hygiene dan Determinannya pada Perawat di Ruang Rawat Inap Gedung X Rumah Sakit Y Jakarta Tahun 2017. Skripsi (dipublikasikan). Jakarta: UINJK.

IKAPI. (2009). Inear Healing at Home. Jakarta: Gramedia.

Iskandar M.B, dan Yanto A. (2018). Pengaruh Pendidikan Kesehatan terhadap Pelaksanaan Cuci Tangan 6 Langkah 5 Momen Keluarga Pasien di Ruang Rawat Inap RS Roemani Semarang. Prosiding Seminar Nasional Mahasiswa Unimus. (Vol. 1, 2018).

Kapti, R.E. (2010). Efektivitas Audiovisual Sebagai Media Penyuluhan Kesehatan terhadap Peningkatan Pengetahuan dan Sikap Ibu dalam Tatalaksana Balita dengan Diare. Tesis. Depok: Universitas Indonesia.

Kementrian Kesehatan RI, 2013, Pedoman Pencegahan dan Penangulangan Infeksi di Rumah Sakit dan Fasilitas Pelayanan Kesehatan Lainnya, Jakarta.

Kurniawati, A. F., Satyabakti, P., \& Arbianti, N. (2015). Perbedaan risiko multidrug resistance organisms (MDROS) menurut faktor risiko dan kepatuhan hand hygiene. Jurnal Berkala Epidemiologi, 3(3), 277-289. https://doi.org/10.20473/jbe.V3I3 2015.277-289.

Kustandi, C, Sujipto, B. 2011. Media Pembelajaran Manual dan Digital. Bogor: Penerbit Ghalia Indonesia.

Maulana, Heri D.J. (2009). Promosi Kesehatan. Jakarta : EGC.

Misoch, S. (2014). Card Stories on YouTube: A New Frame for Online Self-Disclosure. Media and Communication, 2(1), 2-12.
Mumpuningtias ED, Aliftitah S dan Illiyini. (2017). Hubungan Tingkat Pengeahuan dengan Perilaku Cuci Tangan Menggunakan Handrub pada Keluarga Pasien di Ruang Bedah RSUD dr. H. Moh. Anwar Sumenep. Jurnal Publikasi Kesehatan. Program Studi Ilmu Keperawatan Fakultas Ilmu Kesehatan Universitas Wiraraja.

Murdayaningsih R, 2015, Pengaruh Pendidikan Kesehatan Cuci Tangan Terhadap Keaptuhan Mahasiswa Praktek Di Ruanga ICU RSUD Dr. Moewardi. Jurnal Karya Ilmiah. Surakarta: Stikes Kusuma Husada.

Notoatmodjo, S (2010). Promosi Kesehatan dan Ilmu Perilaku. Jakarta : Rineka Cipta.

Nursalam. (2013). Konsep Penerapan Metode Penelitian Ilmu Keperawatan. Jakarta: Salemba Medika.

Raharjo AAK, Putra PWK, dan Darmawan KN, (2017). Pengaruh Pendidikan Kesehatan dengan Media Leaflet terhadap Perilaku Mencuci Tangan Pengunjung di Rumah Sakit Umum Bali Royal. CARING, Volume 1 Nomor 2, Desember 2017.

Rachmawati F, Putri HF. (2016). Pengaruh Penyuluhan tentang Cuci Tangan dengan Media Video terhadap Penerapan Praktik Cuci Tangan di SDN Nogotirto. Naskah Publikasi. Yogyakarta: Universitas 'Aisyiyah Yogyakarta.

Rekam Medis RS Kasih Ibu, 2019. Kejadian Infeksi Nosokomial di Rumah Sakti Kasih Ibu tahun 2918. Surakarta: Bagian Catatan Medis RS Kasih Ibu Surakarta.

WHO. (2015). Guidelines on Hand Hygiene in Health Care. Library Cataloguing-in-Publication Data. 
Zulkarnain. (2009). Infeksi Nosokomial p:2906-2910. In: Buku Ajar Ilmu Penyakit Dalam III. Edisi ke-5. Jakarta: F.K Universitas Indonesia 